\title{
The President's Global Health Initiative
}

Lawrence O. Gostin

Georgetown University Law Center, gostin@law.georgetown.edu

Emily A. Mok

Georgetown University Law Center, eam223@law.georgetown.edu

http://jama.ama-assn.org/cgi/content/extract/304/7/789

This paper can be downloaded free of charge from:

https://scholarship.law.georgetown.edu/facpub/426

304 JAMA 789-790 (2010)

This open-access article is brought to you by the Georgetown Law Library. Posted with permission of the author. Follow this and additional works at: https://scholarship.law.georgetown.edu/facpub

Part of the Health Law and Policy Commons 


\title{
GEORGETOWN LAW Faculty Publications
}

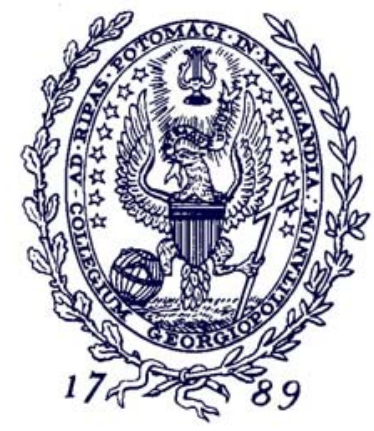

Georgetown Public Law and Legal Theory Research Paper No. 10-51

August 2010

\section{The President's Global Health Initiative*}

\author{
304 JAMA 789-790 (2010)
}

\section{Lawrence O. Gostin \\ Professor of Global Health Law Georgetown University Law Center gostin@law.georgetown.edu}

Emily A. Mok

Adjunct Professor of Law Georgetown University Law Center eam223@law.georgetown.edu

This paper can be downloaded without charge from:

Scholarly Commons: http://scholarship.law.georgetown.edu/facpub/426/ SSRN: http://ssrn.com/abstract $=1663780$

Posted with permission of the author *http://jama.ama-assn.org/cgi/content/extract/304/7/789 


\section{The President's Global Health Initiative}

Lawrence O. Gostin, JD

Emily A. Mok, MGA, MBE

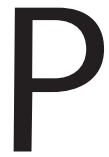

RESIDENT OBAMA'S SIGNATURE HEALTH POLICY INItiative is health care reform. Just as important, but less noticed, is the President's Global Health Initiative (GHI). Building on the President's Emergency Plan for AIDS Relief (PEPFAR) — the largest commitment by any nation to combat a single disease-Mr Obama promised to fundamentally "restructure the US global health enterprise." ${ }^{1}$ However, as the United States enters a period of severe budgetary restraint and as the president focuses his attention on domestic crises (eg, the Gulf Coast oil spill), the promise of global health reform could become illusory. That would be a serious error because global health is vital to US national interests.

\section{Global Health Initiative}

The GHI pledged in 2009 to invest $\$ 63$ billion over 6 years (fiscal years 2009-2014)— \$51 billion for PEPFAR (HIV/ AIDS, tuberculosis, and malaria) and $\$ 12$ billion for broader global health (eg, mother and child health, nutrition, and neglected tropical diseases). ${ }^{2}$ The fiscal year 2011 budget marks the halfway point, bringing cumulative GHI funding to $\$ 26.81$ billion, or $43 \%$ of the total, but the Senate Budget Committee recently voted to cut foreign assistance by $\$ 4$ billion. ${ }^{3}$

The core principles of the GHI include a femalecentered focus, strategic coordination, multilateral engagement, country-ownership, strengthening health systems, evaluation, and research. The GHI details an ambitious array of targets for 2015 to coincide with the Millennium Development Goals-eg, prevent more than 12 million new human immunodeficiency virus (HIV) infections and treat more than 4 million individuals; reduce tuberculosis and malaria prevalence by $50 \%$ each; and reduce mortality among mothers by $30 \%$ and children younger than 5 years by $35 \%$ in assisted countries. The administration is selecting 20 "GHIPlus" countries for accelerated technical, management, and financial resources.

The GHI is unfolding in parallel with 2 foreign assistance reviews: the National Security Council's Presidential Study Directive on Global Development (PSD-7), offering

\section{See also p 791.}

strategic analysis on why and how the United States engages in international development; and the State Department's Quadrennial Diplomacy and Development Review to guide health, development, and diplomacy. ${ }^{4}$

Secretary of State Hillary Clinton frames global health as "smart power," an integral part of the government's "three pillars" of foreign policy-diplomacy, development, and defense. Global health diplomacy-designed to improve health while strengthening international relations-is reflected in US sensitivity to poor countries, generosity in giving, and partnerships with key stakeholders. It is demonstrated through sharing scientific knowledge, collaborative research, and training. Global health diplomacy fosters improved relationships, prestige, and influence. When the United States uses health as a tool of diplomacy, it sends a powerful signal about its national values.

\section{Suggestions for Transforming the US Global Health Enterprise}

Fundamentally Reform the US Foreign Assistance Architecture. The US foreign assistance architecture lacks coherence and a strategic vision, with its wide array of fragmented and siloed programs. The Council on Foreign Relations describes the Foreign Assistance Act of 1961 as "an incoherent document 2000 pages long, with at least 33 different goals, 75 'priority areas,' and 247 directives, executed by 22 implementing agencies." ${ }^{5}$ The US global health architecture, which includes 7 federal departments, 4 independent agencies, and 5 multiagency initiatives, has had no overarching budget, no line management, and little coordination. ${ }^{6}$ Congress should fundamentally reform the Foreign Assistance Act and create clear strategies, priorities, and accountability.

A new management structure is essential to ensuring ample legal authority and resources at a sufficiently high level to raise the visibility and political stature of global health. Strong leadership and clear lines of accountability across numerous agencies (eg, State Department, the Department of Health and Human Services, and the Department of Defense) will be critical factors to success. This could be achieved by ap-

Author Affiliations: O'Neill Institute for National and Global Health Law, Georgetown University Law Center, Washington, DC (Mr Gostin and Ms Mok); and Department of Public Health, Johns Hopkins University, Baltimore, Maryland (Mr Gostin).

Corresponding Author: Lawrence O. Gostin, JD, Georgetown University Law Center, 600 New Jersey Ave NW, Washington, DC 20001 (gostin@law.georgetown .edu).

(Reprinted) JAMA, August 18, 2010—Vol 304, No. $7 \mathbf{7 8 9}$ 
pointing a high-ranking official to report to the president or secretary of state to manage the myriad of competitive foreign policy agendas and act as the central global health authority.

Devote Resources That Are Predictable, Sustainable, and Scalable to Needs. The GHI budget-even if fully funded by Congress-will fail to keep promises or expand the horizons of global health. Global health funding represents less than $1 \%$ of the federal budget-far too little to fund existing commitments and new solutions. Even with the vast expansion of PEPFAR, the United States does not come close to meeting the 1975 pledge of giving $0.7 \%$ of the gross domestic product for development. A substantial proportion of foreign aid goes for geostrategic purposes in Afghanistan, Iraq, and Pakistan rather than for the basic health needs of the world's poor.

The fiscal year 2011 budget proposes a minuscule 2\% increase for PEPFAR, which will result in treatment enrollment freezes and a growing waiting list among 14 million individuals eligible for HIV treatment. At the same time, the GHI cannot achieve its ambitious goals in child and maternal health, tuberculosis, neglected tropical diseases, or health systems without increased funding. Low- and middleincome countries cannot plan for the long term without predictable and sustainable resources that are scalable to meet pressing needs.

Develop a "Whole of Government" Approach. US policies fundamentally affect global health beyond foreign assistance. Agriculture, defense, energy, trade, and the environment can negatively affect poor countries. For example, subsidies to US farmers undermine African farmers' ability to compete. Trade agreements affording pharmaceutical companies enhanced intellectual property protection make essential medicines less affordable in developing countries.

The United States, therefore, should consider adopting a "whole of government" approach to improve coherence across foreign policy realms. Sometimes called "health in all policies," this innovative governance structure would require all departments to consider the global health effects of programs and activities. The World Health Organization recommends an "all of government" approach, which has been successfully used in Switzerland and the United Kingdom.

Collaborate With Partners for Success. "Shared responsibility" is a key GHI principle. Yet the GHI does not indicate how the United States will improve collaboration with international partners such as the World Health Organization (WHO), the Global Fund, and the International Health Partnership. The GHI's distribution of bilateral and multilateral funding from fiscal years 2009-2011 is approximately $86 \%$ and $14 \%$ respectively. ${ }^{7}$ The US contribution to the Global Fund has flatlined at a level far below its fair share of $\$ 2$ billion, which is especially troubling because only $\$ 3$ billion of the total $\$ 10$ billion global commitment has been raised as a result of the global economic crisis. ${ }^{8}$ In the currently crowded global health landscape, the GHI should work more collaboratively with other donors to achieve efficiencies and sustainability rather than create parallel and redundant programs.

Encourage Host Country Ownership. The US approach to working with developing countries also needs to evolve. Foreign assistance often leads to increased dependency, reduced host-country health expenditures, and skewed priorities that do not reflect actual burdens of disease. ${ }^{9}$ To empower developing countries, the GHI should institute the principles of the Paris Declaration on Aid Effectiveness and the Accra Agenda for Action, including promoting country ownership, harmonizing donor actions, aligning with country strategies, establishing mutual accountability, providing aid predictability, and removing aid conditionality. ${ }^{10}$ This set of innovations would transition US engagement from a pattern of "charitable" emergency response to greater selfreliance and sustainability. The deep engagement of civil society will also be a critical factor to better understand local needs and harness the energy of nongovernmental organizations and community-based organizations.

\section{Conclusions}

The GHI offers a unique opportunity to transform global health. The world is poised to fail to achieve the Millennium Development Goals, and recent outbreaks of novel pandemics demonstrate collective vulnerabilities. If the United States reframed foreign assistance from "charitable aid" to sustainable development, it could substantially improve global health while advancing national interests.

Financial Disclosures: None reported.

\section{REFERENCES}

1. Institute of Medicine. The US Commitment to Global Health: Recommendations for the New Administration. Washington, DC: National Academies Press; 2008.

2. USAID. Implementation of the Global Health Initiative: Consultation Document. Washington, DC: USAID. http://www.usaid.gov/our_work/global_health/home /Publications/docs/ghi_consultation_document.pdf. Accessed June 24, 2010.

3. Kates J. The US Global Health Initiative: key issues. The Henry J Kaiser Family Foundation. http://www.kff.org/globalhealth/upload/8063.pdf. April 14, 2010. Accessed June 24, 2010.

4. Garrett L. Global health update, letter to appropriators. Council on Foreign Relations. http://www.cfr.org/content/thinktank/GlobalHealth/GHU_GarrettLettertoAppropriators Apr3010.pdf. April 30, 2010. Accessed June 25, 2010.

5. Garrett $L$. The future of foreign assistance amid global economic and financial crisis: advancing global health in the US development agenda. Council on Foreign Relations. http://www.cfr.org/publication/18167/future_of_foreign_assistance_amid_global_economic_and_financial_crisis.html. January 2009. Accessed June 24, 2010

6. The Henry J. Kaiser Family Foundation. The US government's global health policy architecture: structure, programs, and funding. http://www.kff.org/globalhealth /upload/7881.pdf. April 2009. Accessed June 24, 2010.

7. The Henry J. Kaiser Family Foundation. Distribution of bilateral and multilateral funding in the US Global Health Initiative (GHI) FY 2009-2001. http://www .kff.org/chartfacts.pdf. Accessed June 25, 2010.

8. Roehr B. More people face treatment rationing as AIDS funding is cut. BMJ. 2010;340:c2284.

9. Commission on US Federal Leadership in Health and Medicine. Center for the Study of the Presidency and Congress. A 21st century roadmap for advancing America's health: the path from peril to progress. http://www.thepresidency.org/storage /documents/18651_textproof.pdf. May 2010. Accessed June 7, 2010.

10. OECD. The Paris Declaration and Accra Agenda for Action. http://www.oecd .org/document/18/0,3343,en_2649_3236398_35401554_1_1_1_1,00.html. Accessed June 24, 2010. 